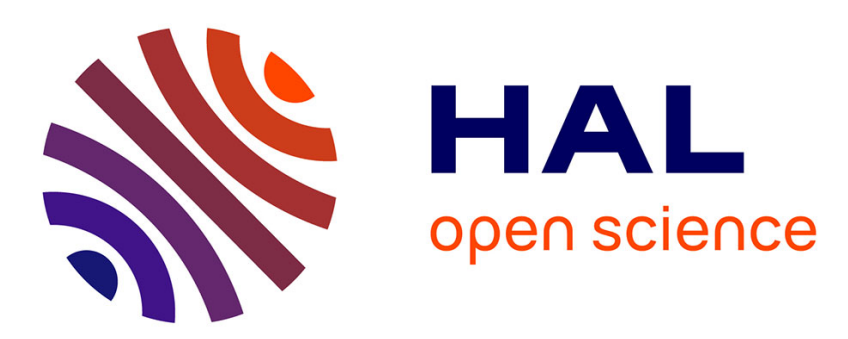

\title{
Prevalence of antibodies against selected agents shared between Cantabrian chamois () and domestic goats
}

\author{
Caterina Falconi, Álvaro Oleaga, Jorge R. López-Olvera, Rosa Casais, Miguel
}

Prieto, Christian Gortázar

\section{- To cite this version:}

Caterina Falconi, Álvaro Oleaga, Jorge R. López-Olvera, Rosa Casais, Miguel Prieto, et al.. Prevalence of antibodies against selected agents shared between Cantabrian chamois () and domestic goats. European Journal of Wildlife Research, 2009, 56 (3), pp.319-325. 10.1007/s10344-009-0322-z . hal00535253

\section{HAL Id: hal-00535253 \\ https://hal.science/hal-00535253}

Submitted on 11 Nov 2010

HAL is a multi-disciplinary open access archive for the deposit and dissemination of scientific research documents, whether they are published or not. The documents may come from teaching and research institutions in France or abroad, or from public or private research centers.
L'archive ouverte pluridisciplinaire HAL, est destinée au dépôt et à la diffusion de documents scientifiques de niveau recherche, publiés ou non, émanant des établissements d'enseignement et de recherche français ou étrangers, des laboratoires publics ou privés. 


\title{
Prevalence of antibodies against selected agents shared between Cantabrian chamois (Rupicapra pyrenaica parva) and domestic goats
}

\author{
Caterina Falconi • Álvaro Oleaga • \\ Jorge R. López-Olvera $\cdot$ Rosa Casais $\cdot$ Miguel Prieto • \\ Christian Gortázar
}

Received: 20 June 2009 /Revised: 9 September 2009 / Accepted: 11 September 2009/Published online: 30 September 2009

(C) Springer-Verlag 2009

\begin{abstract}
Southern chamois (Rupicapra pyrenaica) share the habitat with domestic ungulates, and may, therefore, play a role in the epidemiology of shared agents. The objective of this study was to determine the seroprevalence for Brucella spp., Mycobacterium avium ssp. paratuberculosis (MAP), pestivirus, and Sarcoptes scabiei in Cantabrian chamois (Rupicapra pyrenaica parva) and compare these data with those of sympatric domestic goats (Capra hircus). From 2005 to 2008, blood samples were obtained from 236 adult Cantabrian chamois in two different populations, the western one and the eastern one. Seroprevalence for Brucella spp. and pestivirus was assessed using commercial ELISA kits, whereas specifically designed ELISA tests were used for MAP and S. scabiei. No
\end{abstract}

Communicated by W. Lutz

Caterina Falconi and Álvaro Oleaga contributed equally to this work.

C. Falconi $\cdot$ Á. Oleaga $\cdot$ C. Gortázar

IREC (CSIC-UCLM-JCCM) Ronda de Toledo s.n.,

Ciudad Real 13071, Spain

Á. Oleaga $\cdot$ R. Casais $\cdot$ M. Prieto

SERIDA (Servicio Regional de Investigación

y Desarrollo Agroalimentario),

Laboratorio de Sanidad Animal,

Jove, 33299 Gijón, Asturias, Spain

\section{J. R. López-Olvera $(\triangle)$}

Servei d'Ecopatologia de Fauna Salvatge,

Facultat de Veterinària (Edifici V),

Universitat Autònoma de Barcelona,

Bellaterra, 08193 Barcelona, Spain

e-mail: Jordi.Lopez.Olvera@uab.es

C. Falconi

Via E. de Magistris 9,

09123 Cagliari, Italy antibodies against Brucella spp. were detected. Conversely, antibodies against MAP, pestivirus (chamois 3.8\%; goat $2.3 \%$ ), and S. scabiei (chamois $11.9 \%$; goat $12.8 \%$ ) were detected in both species. Seroprevalence for MAP was significantly higher for domestic goats $(26 \%)$ than for chamois $(9.7 \%)$. In chamois, seroprevalence for pestivirus was higher in the west $(6.5 \%)$ than in the east (range $0-1.8 \%$ ), whereas seroprevalence for $S$. scabiei followed the opposite trend (west 4.6\%; east 16.7-21.4\%). We suggest that certain diseases could circulate between Cantabrian chamois and domestic goat populations, and domestic livestock may suppose a threat for the health status of sympatric Cantabrian chamois.

Keywords Serosurvey - Cantabrian chamois .

Mycobacterium avium ssp. paratuberculosis . Sarcoptic mange $\cdot$ Pestivirus $\cdot$ Domestic goat

\section{Introduction}

Southern chamois (Rupicapra pyrenaica) is a wild mountain ungulate belonging to the Bovidae family and Caprinae subfamily. Two subspecies can be found in Spain: the Pyrenean chamois (Rupicapra pyrenaica pyrenaica) in the Pyrenees and the Cantabrian chamois (Rupicapra pyrenaica parva), endemic from the Cantabrian Mountains and occupying the western limit of the Rupicapra genus distribution area (Fig. 1). A western and an eastern population of Cantabrian chamois, physically separated by anthropogenic barriers, have been defined (Catusse et al. 1996; Shackleton and the IUCN/SSC Caprinae Specialist Group 1997; Pérez-Barbería and García-González 2004). For the purpose of this study, 
the eastern population is shared by two different political regions: Asturias and León.

In 1993, the eastern chamois populations were affected by sarcoptic mange, the disease becoming endemic since then (Fernández-Morán et al. 1997). Sarcoptic mange is considered absent in the western population, without clinical cases of mange detected up to date in this area, where Cantabrian chamois population has continuously increased throughout the last years, reaching a density of 14.35 Cantabrian chamois per square kilometer in 2007. This compares to the 6.50 chamois per square kilometer registered for the mange-affected eastern population in 2007 (Anonymous 2008a, 2008b). Domestic livestock in Asturias and León includes approximately 80,000 domestic goats (Capra hircus; Anonymous 2008c), some of which share habitat in summer with more than 13,500 Cantabrian chamois (ca. 3,400 in the western nucleus, ca. 5,300 in the eastern Asturias one, and ca. 4,800 in the eastern León

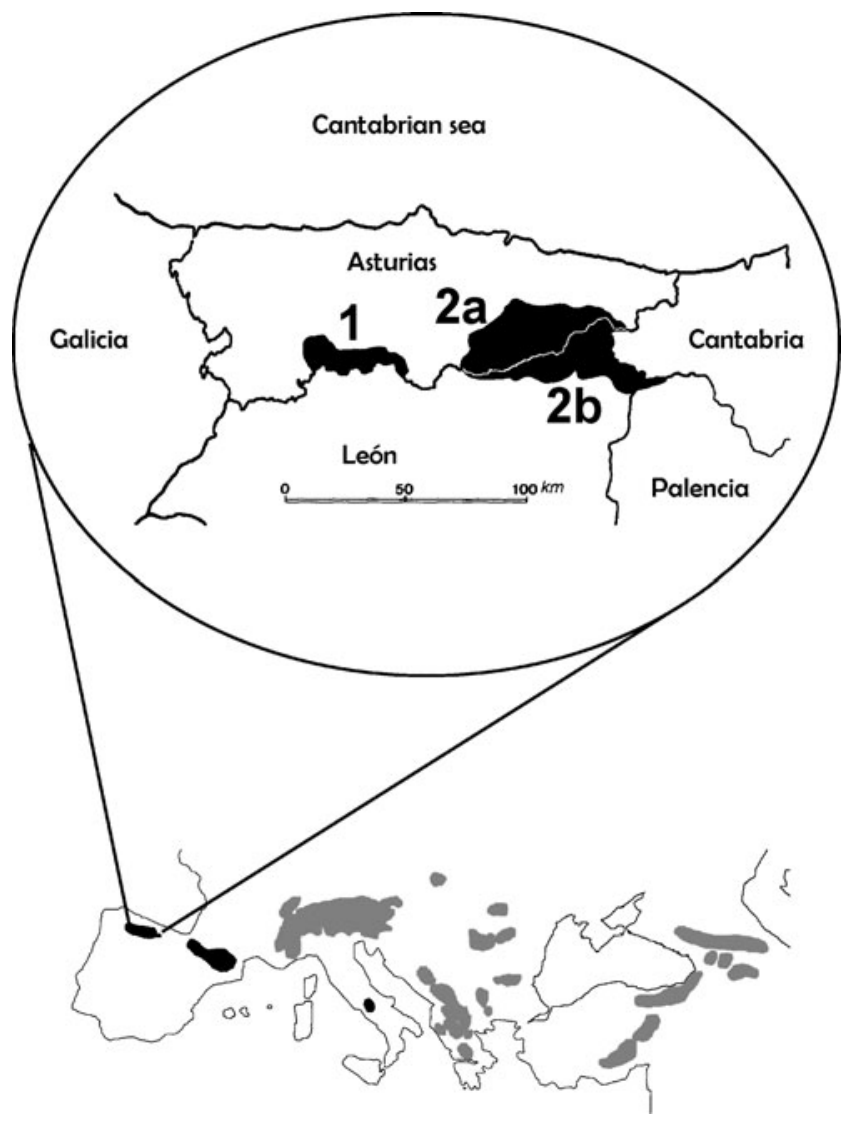

Fig. 1 Chamois distribution in Europe and study areas in northwestern Spain. Adapted and modified from Catusse et al. 1996 and Fernández-Morán et al. 1997. Gray northern chamois (Rupicapra rupicapra) populations, Black southern chamois (Rupicapra pyrenaica) populations, 1 western Cantabrian chamois (Rupicapra pyrenaica parva) population, $2 a$ eastern Cantabrian chamois (Rupicapra pyrenaica parva) population in Asturias, $2 b$ eastern Cantabrian chamois (Rupicapra pyrenaica parva) population in León nucleus) (Pérez-Barbería and García-González 2004; Anonymous 2008a, 2008b).

This commingling may play a significant role in the epidemiology of several infectious agents since crosstransmission may occur as livestock graze in mountain pastures (Gauthier et al. 1991; Cubero-Pablo et al. 2000; Gortázar et al. 2007). Transmission of agents has been suggested in both directions, with wildlife acting as reservoirs of infectious agents which affect domestic animals and livestock being a source of infection for wild mountain ruminants (Bengis et al. 2002; Simpson 2002; Gaffuri et al. 2006).

Antibodies against several infectious agents of ruminants have been detected in chamois (Rupicapra spp.). Antibodies against viral pathogens include bovine herpesvirus 1, encephalomyocarditis virus (Gentile et al. 2000), bovine parainfluenza type 3 virus, bovine respiratory syncytial virus (Gaffuri et al. 2006), and pestivirus (Gentile et al. 2000; Arnal et al. 2004; Hurtado et al. 2004; Gaffuri et al. 2006; Marco et al. 2007; Pioz et al. 2007; Marco et al. 2008). Regarding bacterial agents, antibodies have been detected against Brucella melitensis (Garin-Bastuji et al. 1990), Mycoplasma conjunctivae (Giacometti et al. 2002; Gaffuri et al. 2006), Salmonella enterica, Coxiella burnetii (Pioz et al. 2008), Leptospira interrogans (Gentile et al. 2000), and Chlamydophila abortus (Pioz et al. 2008; Salinas et al. 2009). Finally, antibodies against two protozoa, Neospora caninum and Toxoplama gondii, have also been reported (Gentile et al. 2000; Gaffuri et al. 2006).

In spite of such information regarding other species or subspecies of chamois, only limited information on the seroprevalence of infectious agents in Cantabrian chamois is available (Fernández-Morán et al. 1997; Gauss et al. 2006; Almería et al. 2007). The objective of this study was determining the seroprevalence for Brucella spp., Mycobacterium avium ssp. paratuberculosis (MAP), pestivirus, and Sarcoptes scabiei in the Cantabrian chamois. This was compared with data on sera from sympatric domestic goats sharing summer pastures with the chamois, in order to detect potentially shared diseases between both species.

\section{Materials and methods}

From 2005 to 2008, blood samples were obtained from 236 adult Cantabrian chamois, either hunted $(N=213)$ or life captured with drive-nets $(N=23)$, an already reported method to capture chamois (López-Olvera et al. 2009a). Two different chamois populations were defined according to geographical criteria, the eastern one and the western one, the latter covering an area shared by two different public administrations, León and Asturias (Fig. 1). The 
sampled area represents more than $75 \%$ of the current distribution area of Cantabrian chamois. Since hunting programs are aimed at maintaining population structure balance, animals from both sexes and all ages were included in our sample, thus being representative of the studied population.

Blood samples were collected by jugular venipuncture in the live chamois and by heart puncture in the hunted ones. Blood was allowed to clot at room temperature and centrifuged less than $24 \mathrm{~h}$ after collection. Sera were also obtained from 219 domestic goats through the Official Health Testing Programme of the Spanish government for Brucella abortus. All sera were stored at $-20^{\circ} \mathrm{C}$ until analyzed.

A commercial competitive enzyme-linked assay (ELISA; INGEZIM BRUCELLA BOVINE 1.2.BB.K.1, INGENASA, Madrid, Spain) was used for the detection of antibodies against Brucella spp. according to the manufacturer's recommendations. This ELISA detects antibodies against the protein-polysaccharide complex LPS-S of Brucella, and it has been previously used in mouflon (Ovis aries musimon; López-Olvera et al. 2009b).

An ELISA BVD/Mucosal Disease p80 kit (Institut Pourquier, Montpellier, France) was used to search for pestivirus antibodies, according to the procedure described by the manufacturer, as previously described in Pyrenean chamois (Pioz et al. 2007). The test detects antibodies directed against protein $\mathrm{p} 80 / 125$, common to all pestivirus strains. Samples with a percentage of inhibition equivalent or less than $40 \%$ were considered positive.

Antibodies to MAP were detected using a specifically designed adsorbed ELISA test following protocols reported previously for cattle and sheep (Garrido 2001; Sevilla 2007), as previously used and reported for red deer (Cervus elaphus) (Reyes-García et al. 2008). This test detects antibodies against MAP protoplasmatic antigen 3. The cutoff was set as the mean optical density value of the negative controls added to three times the standard deviation of all negative control.

Antibodies against $S$. scabiei were determined using an "in house" ELISA test based in the use of a recombinant antigen. This test detects the Ss $\lambda 20$ antigen of the parasite, located in the mite's organs, the integument of the epidermis, and the spaces surrounding its vital organs (Casais et al. 2007). This test was characterized by $100 \%$ sensitivity and 97\% specificity in both red deer and southern chamois (Casais et al. 2007), although field trials of the test in red deer revealed a slight decrease of specificity $(97 \%)$ but a stronger decrease of sensitivity, which was $75 \%$ (Oleaga et al. 2008).

A chi-square analysis was performed for all agents, using the PROC FREQ procedure of SAS ${ }^{\circledR}$ System for Windows V8 (SAS Institute Inc., Cary, NC, USA), to detect seroprevalence differences between species, among areas for both species, and among years for southern chamois.

\section{Results}

Table 1 shows the serologic results for both Cantabrian chamois and domestic goat in the different study areas. No antibodies were detected against Brucella spp. either in chamois or goat. Conversely, antibodies against MAP, pestivirus, and $S$. scabiei were detected in both species.

Seroprevalence for MAP was significantly $(P<0.05)$ higher in domestic goats than in Cantabrian chamois for the total and for the west and León areas. Differences in MAP antibodies seroprevalence in goats were also significant among areas.

Seroprevalence for pestivirus in Cantabrian chamois was statistically higher in the western area than in the eastern area. Moreover, pestivirus seroprevalence significantly $(P<0.05)$ increased throughout the years in this species (Table 2).

Seroprevalence for $S$. scabiei in Cantabrian chamois was statistically $(P<0.05)$ higher in the eastern area than in the western area.

\section{Discussion}

The absence of antibodies against Brucella spp. in all the animals examined has been previously reported in the Cantabrian chamois (Fernández-Morán et al. 1997). Our results seem to further confirm that Brucella spp. is apparently not circulating within the wild chamois population and the domestic goat flocks in the study area.

Wild ruminants may become MAP-infected by contact with infected domestic livestock (Riemann et al. 1979; Marco et al. 2002; Deutz et al. 2005; Kopecna et al. 2006), but transmission from wildlife to domestic livestock has also been suspected (Chiodini and Van Kruiningen 1983; Greig et al. 2003). Absence of antibodies against MAP had been previously reported in Cantabrian (González-Quirós et al. 1996; Fernández-Morán et al. 1997) and Abruzzo (Rupicapra pyrenaica ornata) chamois (Gentile et al. 2000). However, paratuberculosis (or specific antibodies) has been recently reported in the fallow (Dama dama) (Marco et al. 2002; Balseiro et al. 2008) and red deer (Reyes-García et al. 2008) in the Cantabrian Mountains. Our results indicate that paratuberculosis is present in the study area both in Cantabrian chamois and domestic goats, livestock probably being a source of MAP-infection for Cantabrian chamois due to their higher seroprevalence of antibodies against MAP. Nevertheless, these results should be considered with caution, since ELISA has demonstrated 


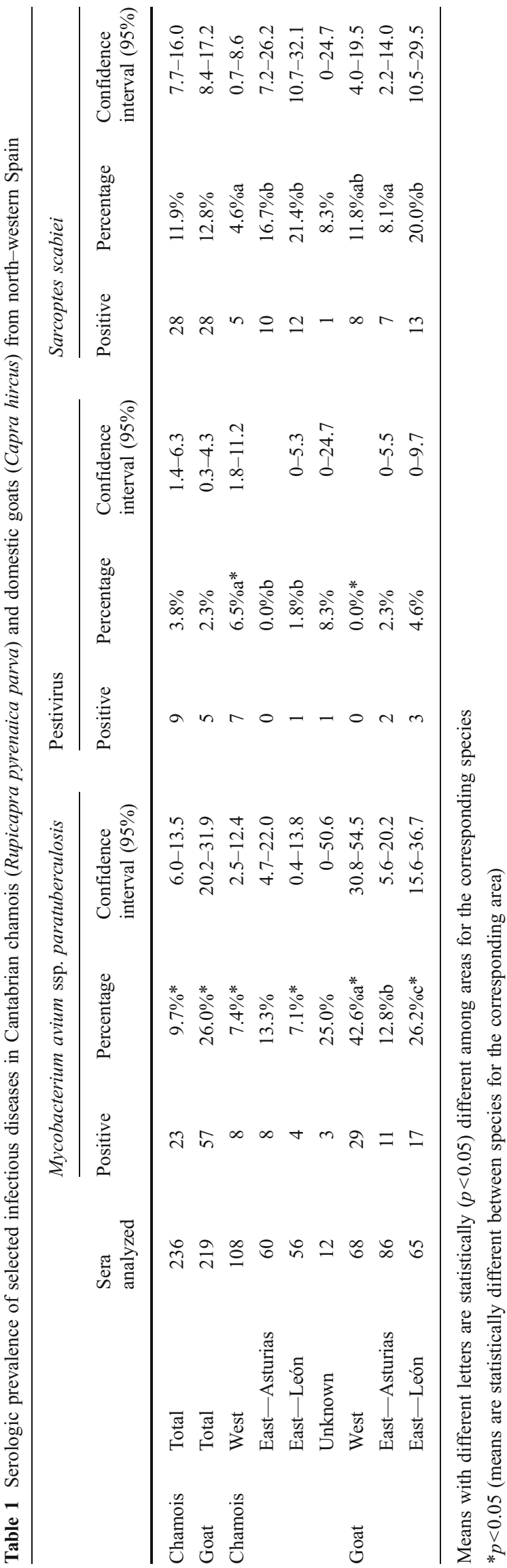

Table 2 Pestivirus seroprevalence in Cantabrian chamois (Rupicapra pyrenaica parva) from north-western Spain according to the year

\begin{tabular}{ccc}
\hline Year & Positive/analyzed & Percentage \\
\hline 2005 & $0 / 7$ & $0.0 \% \mathrm{a}$ \\
2006 & $1 / 61$ & $1.6 \% \mathrm{a}$ \\
2007 & $3 / 153$ & $2.0 \% \mathrm{a}$ \\
2008 & $5 / 15$ & $33.3 \% \mathrm{~b}$ \\
\hline
\end{tabular}

Means with different letters statistically $(P<0.05)$ different from each other

to have a low sensitivity to detect MAP-infected domestic and wild ruminants, with culture and polymerase chain reaction (PCR) MAP-positive animals showing negative ELISA results (Weber et al. 1992; Nebbia et al. 2000; Juste et al. 2005). Strain characterization of MAP isolates from both Cantabrian chamois and domestic goats, as well as other domestic species such as cattle (Balseiro et al. 2003), could help to elucidate the epidemiology of this pathogen in the study area.

To our knowledge, this is the first study to provide data on antibodies against pestivirus for Cantabrian chamois. A mortality outbreak affecting Pyrenean chamois, associated to a newly described pestivirus, has been reported in the western Pyrenees, seroprevalences ranging from $62.8 \%$ to 70.3\% (Hurtado et al. 2004; Frolich et al. 2005; Marco et al. 2007; Pioz et al. 2007; Marco et al. 2008). Unlike the Pyrenees outbreak, no mortality or clinical signs potentially related to pestivirus infection have been observed in our study area. Lower seroprevalences against pestivirus (from $5.6 \%$ to $25.5 \%$ ) without associated virus isolation, clinical signs, or mortality have been previously reported in Pyrenean (Arnal et al. 2004), Abruzzo (Gentile et al. 2000), and Alpine chamois (Rupicapra rupicapra) (Baradel et al. 1988; Olde Riekerink et al. 2005; Gaffuri et al. 2006). The relatively low seroprevalence for pestivirus and the absence of mortality and clinical signs found in the present study are similar to this epidemiological situation. Domestic animals (e.g., sheep) have been considered the origin of pestivirus inducing low seroprevalence in healthy chamois populations (Olde Riekerink et al. 2005; Gaffuri et al. 2006; Marco et al. 2009), due to higher prevalence and relatively frequent detection of persistently infected farm animals (Vilcek and Nettleton 2006), although domestic ungulates can also be infected from wild ungulates through indirect contact (Uttenthal et al. 2005). New high pathogenic virus strains could cause a mortality outbreak, as it has happened in the Pyrenees (Hurtado et al. 2004; Vilcek and Nettleton 2006; Marco et al. 2007), and pestivirus strains circulating in the wildlife-domestic livestock interface should be determined to evaluate the potential risk. However, the phylogenetic grouping of a highly pathogenic pestivirus 
isolated of Pyrenean chamois from France suggests that cross-specific transmission of this isolate from domestic sheep to chamois via shared pastures is unlikely (Frolich et al. 2005).

Statistically, higher pestivirus seroprevalence of Cantabrian chamois as compared to goats in the western area suggests that the virus could circulate in the chamois population alone, or that other domestic ungulates (like sheep or cattle) are participating in the epidemiology of pestivirus. The increase along time of pestivirus seroprevalence in the chamois population, together with the higher seroprevalence against pestivirus found in the western population, agree with the increase in Cantabrian chamois population density in this area, which could ease transmission and circulation of the virus. However, since the ELISA used is unspecific and cross-reactions between different pestivirus exist, virus neutralization tests should be used to determine pestivirus strains circulating in domestic ruminants and Cantabrian chamois in the study area, in order to evaluate the potential risk of disease and mortality for both wildlife and livestock.

Sarcoptic mange, caused by the mite S. scabiei, affects both livestock and wildlife (Menzano et al. 2007; Morner 1992). A sarcoptic mange epizootic affecting the eastern population of Cantabrian chamois was first detected in 1993 and has since then become endemic in this area, without detected clinical cases of sarcoptic mange in the western chamois population up to date (González-Quirós et al. 1996; Fernández-Morán et al. 1997). The statistically significant higher seroprevalence of antibodies against S. scabiei in the eastern population (both in Asturias and León) when compared with the western population agrees with this epidemiological situation. Chamois can be infected with $S$. scabiei mites from domestic goats and develop disease (Lavín et al. 2000), and domestic ruminants are the most probable origin of the sarcoptic mange epidemic which affected Cantabrian chamois in 1993 (Fernández-Morán et al. 1997), as exposed in other outbreaks of sarcoptic mange in wild Bovidae species (Vyrypaev 1985; León-Vizcaino et al. 1999; GonzálezCandela et al. 2004; Rossi et al. 2007). Conversely to Spanish ibex, antimange antibodies have a certain protective effect in southern chamois (Lastras et al. 2000), and therefore, the six seropositive Cantabrian chamois found in the western population are probably related to contact with mites from mange-infected domestic goats. The western population can still be considered mange-free, since S. scabiei causes high morbidity in chamois, and clinical cases seem to be required to confirm that a chamois population is affected by mange (Rossi et al. 1995; Fernández-Morán et al. 1997; Rossi et al. 2007).

Statistically, significant higher mange seroprevalence of the goats from León compared to Asturias within the eastern population is probably related to differences in the sanitary management of the two administrations involved (Pérez-Barbería and García-González 2004). However, no similar differences in chamois seroprevalence were found among areas. This could indicate that sarcoptic mange has become endemic in the eastern chamois population (both in Asturias and León) and is self-maintained independently from domestic livestock. The presence of mange antibodies in the Western population of Cantabrian chamois and the almost statistically significant $(P=0.07)$ higher seroprevalence of goats in this area suggest that domestic goats are a threat of a new mange epidemic for the currently unaffected western chamois population. Measures to control mange, including treating domestic livestock and monitoring animal movements between affected and unaffected zones, together with effective measures to reduce Cantabrian chamois population, especially in the high-density Western area, should be undertaken in order to prevent the spread of this disease and the emergence of new mange epizootics.

To summarize, this is the first study to provide systematic data on seroprevalence of several infectious diseases in the Cantabrian chamois population. MAP, pestivirus, and sarcoptic mange are present in the population of Cantabrian chamois and domestic goats in the Cantabrian Mountains. Although higher MAP seroprevalence of goats seems to suggest that they could be maintaining this disease, a long-time MAP surveillance including strain characterization in wildlife and domestic livestock is needed in order to better understand the role of Cantabrian chamois and the sympatric domestic population in the epidemiology of paratuberculosis. Presence of antibodies against pestivirus has been reported for the first time in Cantabrian chamois. Surveillance of pestivirus and strain determination in domestic ungulates and Cantabrian chamois is crucial for the early detection of new or known pestivirus which could cause a mortality outbreak. Domestic goats could be a risk regarding sarcoptic mange in the currently chamois mange-free western range. Control measures should be taken to prevent new epizootics in the chamois population, such as the previously reported ones in the Cantabrian Mountains and the Pyrenees, caused by mange and pestivirus, respectively. By contrast, the absence of relevant disease such as Brucella in chamois and the lower seroprevalence of MAP suggest that chamois do not carry sanitary risks for domestic goats in the study area.

Acknowledgments R. Casais is recipient of a "Ramón y Cajal" contract from the Spanish Ministerio de Ciencia e Innovación (MCINN) cofinanced by the European Social Fund. Research involving development of an ELISA for the diagnosis of Sarcoptes scabiei has been supported by Grant RTA2006-00046 from the Spanish Instituto Nacional de Investigación y Tecnología Agraria y Alimentaria (INIA). This is a contribution to grant AGL2008-03875 on paratuberculosis in Spanish wildlife, awarded by the Spanish 
(MCINN). Special thanks to rangers, technicians, and administration from Principado de Asturias and Regional Hunting Reserves of León. Wildlife disease surveillance in Asturias is supported by Principado de Asturias and the Spanish Consejo Superior de Investigaciones Científicas (CSIC). C. Falconi acknowledges a grant from the Government of Sardegna.

\section{References}

Almería S, Vidal D, Ferrer D, Pabon M, Fernández-de-Mera MI, RuizFons F, Alzaga V, Marco I, Calvete C, Lavín S, Gortázar C, LópezGatius F, Dubey JP (2007) Seroprevalence of Neospora caninum in non-carnivorous wildlife from Spain. Vet Parasitol 143:21-28

Anonymous (2008a) Gobierno del Principado de Asturias, Censo de rebeco en la zona occidental de Asturias. Año 2007. Unpublished report.

Anonymous (2008b) Gobierno del Principado de Asturias, Censo de rebeco en las Reservas Regionales de Caza de la Zona oriental de Asturias (Aller, Caso, Piloña y Ponga). Año 2007. Unpublished report.

Anonymous (2008c) Spain Government, Encuesta ganaderas, resultados año 2008, Ministerio de Medio Ambiente y Medio Rural y Marino, available online http://www.mapa.es/es/estadistica/pags/ encuestaganadera/encuesta.htm. Last accessed 2009/06/19

Arnal MC, Fernández-de-Luco D, Riba L, Maley M, Gilray J, Willoughby K, Vilcek S, Nettleton PF (2004) A novel pestivirus associated with deaths in Pyrenean chamois (Rupicapra pyrenaica pyrenaica). J Gen Virol 85:3653-3657

Balseiro A, Prieto JM, Espí A, Pérez V, García Marín JF (2003) Presence of focal and multifocal paratuberculosis lesions in mesenteric lymph nodes and the ileocaecal valve of cattle positive to the tuberculin test. Vet J 16:210-212

Balseiro A, García Marín JF, Solano P, Garrido JM, Prieto JM (2008) Histopathological classification of lesions observed in natural cases of paratuberculosis in free-ranging fallow deer (Dama dama). J Comp Pathol 138(4):180-188

Baradel JM, Barrat J, Blancou J, Boutin JM, Chastel C, Dannacher G, Delorme D, Gerard Y, Gourreau JM, Kihm U, Larenaudie B, Le Goff C, Pastoret PP, Perreau P, Schwers A, Thiry E, Trap D, Uilenberg G, Vannier P (1988) Results of a serological survey of wild mammals in France. Rev Sci Tech OIE 7:873-883

Bengis RG, Kock RA, Fisher J (2002) Infectious animal diseases: the wildlife/livestock interface. Rev Sci Tech OIE 21(1):53-65

Casais R, Prieto M, Balseiro A, Solano P, Parra F, Martín-Alonso JM (2007) Identification and heterologous expression of a Sarcoptes scabiei cDNA encoding a structural antigen with immunodiagnostic potential. Vet Parasitol 154:103-113

Catusse M, Corti R, Cugnase JM, Dubray D, Gibert P, Michellet J (1996) Les chamois et les isards. In: Le grande faune de montagne. Haitier Littérature Générale, Paris, France, pp 17-69

Chiodini RJ, Van Kruiningen HJ (1983) Eastern white-tailed deer as reservoir of ruminant paratuberculosis. J Am Vet Med Assoc 182:168-169

Cubero-Pablo MJ, Plaza M, Pérez L, González M, León-Vizcaíno L (2000) Seroepidemiology of chlamydial infections of wild ruminants in Spain. J Wildl Dis 36:35-47

Deutz A, Spergser J, Wagner P, Rosengarten R, Köfer J (2005) Mycobacterium avium ssp. paratuberculosis in wild animal species and cattle in Styria/Austria. Berl Munch Tierarztl Wochenschr 118(7-8):314-320

Fernández-Morán J, Gómez S, Ballesteros F, Quirós P, Benito LM, Feliu C, Nieto JM (1997) Epizoology of sarcoptic mange in a population of cantabrian chamois (Rupicapra rupicapra parva) in northwestern Spain. Vet Parasitol 73:163-171
Frolich K, Jung S, Ludwig A, Lieckfeldt D, Gibert P, Gauthier D, Hars J (2005) Detection of a newly described pestivirus of Pyrenean chamois in France. J Wildl Dis 41:606-610

Gaffuri A, Giacometti M, Tranquillo MV, Magnino S, Cordioli P, Lanfranchi P (2006) Serosurvey of roe deer, chamois and domestic sheep in the Central Italian Alps. J Wildl Dis 42 (3):685-690

Garin-Bastuji B, Oudar J, Richard Y, Gastellu J (1990) Isolation of Brucella melitensis Biovar 3 from chamois (Rupicapra rupicapra) in the Southern French Alps. J Wildl Dis 26:116-118

Garrido JM (2001) Puesta a punto de técnicas de PCR en heces y de ELISA para el diagnóstico de la paratuberculosis. Estudio de prevalencia en ganado bovino. PhD Thesis, Universidad de Zaragoza, Zaragoza, Spain

Gauss CBL, Dubey JP, Vidal D, Cabezón O, Ruiz-Fons F, Vicente J, Marco I, Lavín S, Gortázar C, Almería S (2006) Prevalence of Toxoplasma gondii antibodies in red deer (Cervus elaphus) and other wild ruminants from Spain. Vet Parasitol 136:193-200

Gauthier D, Gibert P, Hars J (1991) Sanitary consequences of mountain cattle breeding on wild ungulates. Ungulates 91:621630

Gentile L, Mari F, Cardeti G, Macrì G (2000) Serologic survey in a chamois population of Abruzzo. Hystrix 11(2):115-119

Giacometti M, Janovsky M, Jenny H, Nicolet J, Belloy L, Goldschmidt-Clermont E, Frey J (2002) Mycoplasma conjunctivae infection is not maintained in Alpine chamois in eastern Switzerland. J Wildl Dis 38:297-304

González-Candela M, León-Vizcaíno L, Cubero-Pablo MJ (2004) Population effects of sarcoptic mange in Barbary sheep (Ammotragus lervia) from Sierra Espuña Regional Park, Spain. J Wildl Dis 40(3):456-465

González-Quirós P, Fernández JP, Benito JL, Ballesteros F (1996) A recent outbreak of sarcoptic mange in Cantabrian chamois (Rupicapra pyrenaica parva). In: Botev N (ed) Proceedings of the 22nd Congress of the International Union of Game Biologists 1995. Sofia, Bulgaria, pp 475-479

Gortázar C, Ferroglio E, Höfle U, Frölich K, Vicente J (2007) Diseases shared between wildlife and livestock: a European perspective. Eur J Wildl Res 53:241-256

Greig A, Beard P, Daniels MJ, Henderson D, Hutchings MR, Stevenson K (2003) The potential role of wildlife in the epidemiology of paratuberculosis in domestic animals. Proceedings of the 7th International Colloquium on Paratuberculosis, Bilbao, Spain, June 11-14 2002, p 89

Hurtado A, Adúriz G, Gómez N, Oporto B, Juste RA, Lavín S, LópezOlvera J, Marco I (2004) Molecular identification of a new pestivirus associated to an outbreak of disease in the Pyrenean chamois (Rupicapra pyrenaica pyrenaica) in Spain. J Wildl Dis 40(4):796-800

Juste RA, Garrido JM, Geijo M, Elguezabal N, Aduriz G, Atxaerandio R, Sevilla I (2005) Comparison of blood polymerase chain reaction and enzyme-linked immunosorbent assay for detection of Mycobacterium avium ssp. paratuberculosis infection in cattle and sheep. J Vet Diagn Invest 17:354-359

Kopecna M, Lamka J, Parmova I, Trcka I, Svastova P, Bartos M, Pavlik I (2006) Paratuberculosis in wild ruminants in the Czech Republic from 1997 to 2004. Veterinarski arhiv 76(Suppl):S19S26

Lastras ME, Pastor J, Marco I, Ruiz M, Viñas L, Lavín S (2000) Effects of sarcoptic mange on serum proteins and immunoglobulin G levels in chamois (Rupicapra pyrenaica) and Spanish ibex (Capra pyrenaica). Vet Parasitol 88:313-319

Lavín S, Ruiz-Bascarán M, Marco I, Fondevila MD, Ramis AJ (2000) Experimental infection of chamois (Rupicapra pyrenaica parva) with Sarcoptes scabiei derived from naturally infected goats. J Vet Med B 47:693-699 
León-Vizcaino L, Ruiz de Ybañez MR, Cubero MJ, Ortiz JM, Espinosa J, Pérez L, Simón MA, Alonso F (1999) Sarcoptic mange in Spanish ibex from Spain. J Wildl Dis 35(4):647-659

López-Olvera JR, Marco I, Montané J, Casas-Díaz E, Mentaberre G, Lavín S (2009a) Comparative evaluation of effort, capture and handling effects of drive nets to capture roe deer (Capreolus capreolus), southern chamois (Rupicapra pyrenaica) and Spanish ibex (Capra pyrenaica). Eur J Wildl Res 55(3):193-202

López-Olvera JR, Vidal D, Vicente J, Pérez M, Luján L, Gortázar C (2009b) Serological survey of selected infectious diseases in mouflon (Ovis aries musimon) from south-central Spain. Eur J Wildl Res 55(1):75-79

Marco I, Ruiz M, Juste R, Garrido JM, Lavín S (2002) Paratuberculosis in free-ranging fallow deer in Spain. J Wildl Dis 38 (3):629-632

Marco I, López-Olvera JR, Rosell R, Vidal E, Hurtado A, Juste R, Pumarola M, Lavín S (2007) Severe outbreak of disease in southern chamois (Rupicapra pyrenaica) associated with border disease virus infection. Vet Microbiol 120:33-41

Marco I, Rosell R, Cabezón O, Mentaberre G, Casas E, Velarde R, López-Olvera JR, Hurtado A, Lavín S (2008) Epidemiological study of border disease virus infection in Southern chamois (Rupicapra pyrenaica) after an outbreak of disease in the Pyrenees (NE Spain). Vet Microbiol 127:29-38

Marco I, Rosell R, Cabezón O, Benería M, Mentaberre G, Casas E, Hurtado A, López-Olvera JR, Lavín S (2009) Serologic and virologic investigations of pestivirus infection in wild and domestic ruminants in the Pyrenees (NE Spain). Res Vet Sci $87: 149-153$

Menzano A, Rambozzi L, Rossi L (2007) A severe episode of wildlife-derived scabies in domestic goats in Italy. Small Rumin Res 70:154-158

Morner T (1992) Sarcoptic mange in Swedish wildlife. Rev Sci Tech OIE 11(4):1115-1121

Nebbia P, Robino P, Ferroglio E, Rossi L, Meneguz G, Rosati S (2000) Paratuberculosis in red deer (Cervus elaphus hippelaphus) in the western Alps. Vet Res Commun 24:435-443

Olde Riekerink RGM, Dominici A, Barkema HW, De Smit AJ (2005) Seroprevalence of pestivirus in four species of Alpine wild ungulate in the High Valley of Susa, Italy. Vet Microbiol 108:297-303

Oleaga A, Casais R, González-Quirós P, Prieto M, Gortázar C (2008) Sarcoptic mange in red deer from Spain: improved surveillance or disease emergence? Vet Parasitol 154:103-113

Pérez-Barbería FJ, García-González R (2004) Rebeco-Rupicapra pyrenaica. In: Carrascal LM, Salvador A (eds) Enciclopedia Virtual de los Vertebrados Españoles. Museo Nacional de Ciencias Naturales, Madrid. http://www.vertebradosibericos.org/. Last accessed 2009/06/19
Pioz M, Loison A, Gibert P, Dubray D, Menaut P, Le Tallec B, Artois M, Gilot-Fromont E (2007) Transmission of a pestivirus infection in a population of Pyrenean chamois. Vet Microbiol 119:19-30

Pioz M, Loison A, Gauthier D, Gibert P, Jullien JM, Artois M, Gilot-Fromont E (2008) Diseases and reproductive success in a wild mammal: example in the Alpine chamois. Oecologia 155:691-704

Reyes-García R, Pérez-de-la-Lastra JM, Vicente J, Ruiz-Fons F, Garrido JM, Gortázar C (2008) Large-scale ELISA testing of Spanish red deer for paratuberculosis. Vet Immunol Immunopathol 124(1-2):75-81

Riemann H, Zaman MR, Ruppanner R, Aalund O, Jorgensen JB, Worsaae H, Behymer D (1979) Paratuberculosis in cattle and free-living exotic deer. J Am Vet Med Assoc 174:841-843

Rossi L, Meneguz PG, De Martin P, Rodolfi M (1995) The epizootiology od sarcoptic mange in chamois, Rupicapra rupicapra, from the Italian Eastern Alps. Parassitologia 37:233240

Rossi L, Fraquelli C, Vesco U, Permunian R, Sommavilla GM, Carmignola G, Da Pozzo R, Meneguz PG (2007) Descriptive epidemiology of a scabies epidemic in chamois in the Dolomite Alps, Italy. Eur J Wildl Res 53(2):131-141

Salinas J, Caro MR, Vicente J, Cuello F, Reyes-Garcia AR, Buendía AJ, Rodolakis A, Gortázar C (2009) High prevalence of antibodies against Chlamydiaceae and Chlamydophila abortus in wild ungulates using two 'in house' blocking-ELISA tests. Vet Microbiol 135(1-2):46-53

Sevilla I (2007) Caracterización molecular, detección y resistencia de Mycobacterium avium subspecies paratuberculosis. $\mathrm{PhD}$ Thesis. Universidad del País Vasco, Vitoria-Gasteiz, Spain

Shackleton DM, the IUCN/SSC Caprinae Specialist Group (1997) Wild sheep and goats and their relatives: status survey and conservation action plan for Caprinae. Shackleton DM (ed), IUCN, Gland, Switzerland and Cambridge, UK, pp 125-126

Simpson VR (2002) Wild animals as reservoirs of infection disease in the UK. Vet J 163:128-146

Uttenthal A, Grondahl C, Hoyer MJ, Houe H, van Maanen C, Rasmussen TB, Larsen LE (2005) Persistent BVDV infection in mousedeer infects calves. Do we know the reservoirs of BVDV? Prev Vet Med 72:87-91

Vilcek S, Nettleton PF (2006) Pestivirus in wild animal. Vet Microbiol 116:1-12

Vyrypaev VA (1985) The influence of an epizootic of Sarcoptes scabiei infection on a population of the central Asiatic mountain ibex (Capra sibirica) in Tien-Shan. Parazitologiya 19:190-194

Weber A, Gurke R, Bauer K, Schreyer K (1992) Bacterial studies on the occurrence of Mycobacterium paratuberculosis in fecal samples of zoo ruminants. Berl Munch Tierarztl Wochenschr 105(5):161-164 